\title{
KEPADATAN HUNIAN, VENTILASI DAN PENCAHAYAAN TERHADAP KEJADIAN TB PARU DI WILAYAH KERJA PUSKESMAS BINANGA KABUPATEN MAMUJU SULAWESI BARAT
}

\author{
Dina Mariana ${ }^{1}$, Miftah Chairani ${ }^{2}$ \\ ${ }^{1}$ Jurusan Kebidanan Poltekkes Kemenkes Mamuju \\ ${ }^{2}$ Jurusan Kesehatan Lingkungan Poltekkes Kemenkes Mamuju
}

\begin{abstract}
The home environment is one of the potential factors in the spread of Pulmonary Tuberculosis incidence. This study aims to analyze the environmental risk factors of the incidence of Pulmonary Tuberculosis in the working area Puskesmas Binanga Mamuju 2016. The study design is a casecontrol study. Sample size of 93 with a comparison between case and control 1: 2. TB case sample 31 patient and control sample 62 people. TB cases are pulmonary TB patients and controls, not the lungs. The data were collected by interview using questionnaire. Bivariate statistic test using Odds Ratio with $\alpha=0,05$. The results showed that residential density (OR 1.969, 95\% CI: $0.641-6.049$ ), Ventilation (OR 1.492, 95\% CI: 0.576-3.863), and Lighting (OR 6.471, 95\% CI: 0.795 - 52.6) significant to the incidence of pulmonary TB.
\end{abstract}

\section{Keywords: Pulmonary Tuberculosis, Residential Density, Ventilation, Lighting}

\section{PENDAHULUAN}

Tuberkulosis (TB) merupakan penyakit menular langsung yang disebabkan oleh bakteri Mycobacterium tuberculosis dan merupakan penyakit yang mudah menular dalam tahuntahun terakhir memperlihatkan peningkatan dalam jumlah kasus baru maupun jumlah angka kematian yang disebabkan oleh Tuberculosis. WHO dalam Annual Report on Global TB Control 2003 menyatakan terdapat 22 negara yang dikategorikan sebagai high-burden countries terhadap TB Paru, termasuk Indonesia. Bila tidak ditangggulangi setiap orang dengan TB paru aktif akan menginfeksi rata-rata $10-15$ orang pertahunnya (WHO dalam Musadad, 2006).

Penyakit TB paru masih menjadi salah satu masalah kesehatan masyarakat di Indonesia dan merupakan penyebab kematian utama ketiga setelah penyakit jantung dan saluran pernafasan.Hasil Riset Kesehatan Dasar (RISKESDAS) tahun 2013 menunjukkan Prevalensi penduduk Indonesia yang didiagnosis TB paru oleh tenaga kesehatan adalah 0.4 persen. Lima provinsi dengan TB paru tertinggi adalah Jawa Barat (0.7\%), Papua (0.6\%), DKI Jakarta (0.6\%), Gorontalo (0.5\%), Banten (0.4\%) dan Papua Barat (0.4\%) (Riskesdas, 2013). Berdasarkan Profil Kesehatan Indonesia Tahun 2015 Angka notifikasi kasus baru tuberkulosis paruterkonfirmasi bakteriologis pada tahun 2015 di Indonesia sebesar 74 per 100.000 penduduk, sedangkan angka notifikasi seluruh kasus tuberkulosis pada tahun 2015 sebesar 130 per 100.000 penduduk meningkat dibandingkan tahun 2014 sebesar 129 per 100.000 penduduk. Provinsi dengan CNR (Case Notification Rate) semua kasus tuberkulosis tertinggi yaitu Sulawesi Utara (238 per 100.000 penduduk), Papua Barat (235 per 100.000 penduduk), dan DKI Jakarta (222 per 100.000 penduduk). Sementara Sulawesi Barat sebesar 117 per 100.000 penduduk (Profil Indonesia, 2015).

Prevalensi TB Paru di Kabupaten Mamuju pada tahun 2012 sebesar 123/100.000 penduduk. Angka penememuan kasus baru TB Paru BTA + sebesar 316 kasus dari 364 yang diperkirakan atau sebesar $86,26 \%$, dimana data ini menunjukkan adanya peningkatan kasus dari tahun 2011 (46,24\%). Angka CNR kasus baru BTA + pada tahun 2013 sebesar 189 orang atau 56,09 per 100.000 penduduk. Jumlah kasus TB Paru pada tahun 2014 mengalami peningkatan sebesar 235 orang atau CNR kasus baru sebesar 92,62 per 100.000 penduduk. Berdasarkan pencatatan dan pelaporan kasus TB Paru dari Dinas Kesehatan Kabupaten Mamuju, Puskesmas Binangan merupakan wilayah yang tertinggi kasusnya dalam kurun waktu tiga tahun terakhir. Dimana angka penemuan kasus baru meningkat di Puskesmas Binanga yang mana tercatat pada tahun 2012 sebanyak 47 kasus mengalami peningkatan pada tahun 2014 menjadi 58 kasus. 
Masih tingginya prevalensi TB Paru di masyarakat, cakupan program penanggulangan dengan strategi DOTS yang masih perlu untuk ditingkatkan, serta masih tingginya angka putus berobat penderita TB Paru, sehingga aspek pengendalian faktor risiko penularan menjadi penting untuk diperhatikan. Salah satu faktor risiko yang erat hubungannya dengan penularan kejadian TB paru adalah kondisi lingkungan perumahan meliputi suhu dalam rumah, ventilasi, pencahayaan dalam rumah, kelembaban rumah, kepadatan penghuni, dan lingkungan sekitar rumah (Rusnoto, 2008). Penelitian ini bertujuan untuk mengetahui faktor risiko kepadatan hunian, ventilasi dan pencahayaan terhadap kejadian TB Paru di Wilayah Kerja Puskesmas Binanga Kabupaten Mamuju Provinsi Sulawesi Barat.

\section{BAHAN DAN METODE Jenis Penelitian}

Jenis penelitian yang digunakan adalah observasional analitik dengan desain Case Control Study.

\section{Lokasi Penelitian}

Penelitian ini dilaksanakan di wilayah kerja Puskesmas Binanga Kecamatan Mamuju Kabupaten Mamuju Provinsi Sulawesi Barat.

\section{Populasi dan Sampel.}

Populasi penelitian ini adalah seluruh masyarakat yang bertempat tinggal di wilayah kerja Puskesmas Binanga Kecamatan Mamuju Kabupaten Mamuju. Besar sampel yang diperoleh adalah 93 orang dengan perbandingan besar sampel kasus dan kontrol adalah 1:2 (Lemeshow, et.al. 1997). Kasus adalah pasien yang menderita TB paru yang menjalani pengobatan di Puskesmas Binanga sebanyak 31 orang dan sedangkan kontrol adalah masyarakat yang tidak menderita TB paru dan berdomisili di dekat Rumah Penderita TB Paru.

Pengambilan sampel menggunakan teknik Purposive sampling, dengan kriteria inklusi adalah pasien yang berusia $\geq 18$ tahun. Sedangkan kriteria esklusi adalah pasien yang berusia < 18 tahun, dan menderita penyakit kronik selain TB Paru.

\section{Pengumpulan Data}

Pengumpulan data melalui wawancara langsung kepada responden dengan menggunakan kuisioner. Variabel tingkat pencahayaan diukur dengan menggunakan lux meter. Data status pasien TB paru sebagai data sekunder untuk melengkapi data penelitian.

\section{Analisis Data}

Analisis data untuk menguji variabel yang diteliti, yaitu analisis Univariat dan Bivariat. Analisis univariat dilakukan dengan statistik deskriptif untuk melihat frekuensi dan distribusi karakteristik umu responden. Analisis Bivariat dilakukan untuk mengetahui besar risiko kepadatan hunian, ventilasi dan pencahayaan terhadap kejadian TB paru dengan menggunakan perhitungan Odds Ratio.

\section{HASIL}

Hasil Analisis Univariat

Pada tahap ini dilakukan analisis univariat untuk karakteristik umum responden yang mencakup jenis kelamin, umur, kelurahan, pendidikan, pekerjaan, lama pengobatan responden yang menderita TB Paru. Dapat dilihat pada Tabel 1 .

\section{Hasil Analisis Bivariat}

Variabel terikat pada penelitian ini adalah kejadian TB paru dan variabel bebas adalah kepadatan hunian, ventilasi, pencahayaan dan akses fasilitas kesehatan.

\section{PEMBAHASAN}

TB paru merupakan salah satu penyakit berbasis lingkungan yang dapat ditularkan melalui udara. Keadaan berbagai lingkungan yang ditularkan dapat mempengaruhi penyebaran TB salah satunya berawal dari kondisi tempat tinggal, lingkungan rumah. Lingkungan rumah merupakan salah satu faktor yang berhubungan dengan status kesehatan penghuninya yang berperan dalam penyebaran kuman TB paru.Kuman TB paru dapat hidup 1 - 2 jam, berhari-hari bahkan sampai berminggu-minggu tergantung pada ada tidaknya sinar matahari, ventilasi, suhu, kelembaban dan kepadatan hunian.

Kepadatan hunian merupakan salah satu indikator pemicu tingginya tingkat penularan TB Paru. Kepadatan penghuni dalam satu rumah tinggal akan memberikan pengaruh bagi penghuninya. Luas rumah yang tidak sebanding dengan jumlah penghuninya akan menyebabkan berjubel (over crowded). Hal ini tidak sehat karena disamping menyebabkan kurangnya konsumsi oksigen, juga bila salah 
satu anggota keluarga terkena penyakit infeksi, terutama tuberkulosis akan mudah menular kepada anggota keluarga lain (Notoatmodjo, 2007). Kepadatan hunian untuk seluruh rumah biasanya dinyatakan dengan $\mathrm{m}^{2} /$ orang. Luas minimum per orang sangat relatif, tergantung dari kualitas bangunan dan fasilitas yang tersedia. Kepadatan hunian adalah perbandingan jumlah penghuni dengan luas ruangan rumah yang ditempati responden dalam satuan meter persegi $\left(\mathrm{m}^{2}\right)$, dengan persyaratan minimum $8 \mathrm{~m}^{2} /$ orang.

Tabel 1. Distribusi Karakteristik Responden di Wilayah Kerja Puskesmas Binanga Kabupaten Mamuju Tahun 2016

\begin{tabular}{|c|c|c|c|c|c|c|}
\hline \multirow{2}{*}{ Karakteristik Responden } & \multicolumn{2}{|l|}{ Kasus } & \multicolumn{2}{|c|}{ Kontrol } & \multicolumn{2}{|c|}{ Jumlah } \\
\hline & $\mathrm{n}=\mathbf{3 1}$ & $\%$ & $n=62$ & $\%$ & $\mathrm{n}=93$ & $\%$ \\
\hline \multicolumn{7}{|l|}{ Kelurahan } \\
\hline Binanga & 16 & 51,6 & 32 & 51,6 & 48 & 51,6 \\
\hline Karema & 7 & 22,6 & 14 & 22,6 & 21 & 22,6 \\
\hline Kasiwa & 1 & 3,2 & 2 & 3,2 & 3 & 3,2 \\
\hline Mamunyu & 6 & 19,4 & 12 & 19,4 & 18 & 19,4 \\
\hline Rimuku & 1 & 3,2 & 2 & 3,2 & 3 & 3,2 \\
\hline \multicolumn{7}{|l|}{ Kelompok Umur } \\
\hline $18-25$ Tahun & 9 & 29 & 10 & 16,1 & 19 & 20,4 \\
\hline 26 - 33 Tahun & 6 & 19,4 & 17 & 27,4 & 23 & 24,7 \\
\hline $34-41$ Tahun & 3 & 9,7 & 17 & 27,4 & 20 & 21,5 \\
\hline $42-49$ Tahun & 4 & 12,9 & 6 & 9,7 & 10 & 10,7 \\
\hline $50-57$ Tahun & 2 & 6,4 & 5 & 8,1 & 7 & 7,5 \\
\hline $58-65$ Tahun & 2 & 6,4 & 3 & 4,8 & 5 & 5,4 \\
\hline 66 Tahun & 5 & 16,2 & 4 & 6,5 & 9 & 9,8 \\
\hline \multicolumn{7}{|l|}{ Jenis Kelamin } \\
\hline Laki-laki & 17 & 54,8 & 24 & 38,7 & 41 & 44,1 \\
\hline Perempuan & 14 & 45,2 & 38 & 61,3 & 52 & 55,9 \\
\hline \multicolumn{7}{|l|}{ Tingkat Pendidikan } \\
\hline Tidak Sekolah & 0 & 0 & 2 & 3,2 & 2 & 2,2 \\
\hline Tidak Tamat SD & 2 & 6,4 & 3 & 4,8 & 5 & 5,4 \\
\hline SD & 10 & 32,3 & 12 & 19,4 & 22 & 23,6 \\
\hline SMP/sederajat & 5 & 16,1 & 7 & 11,3 & 12 & 12,9 \\
\hline SMA/sederajat & 10 & 32,3 & 20 & 32,3 & 30 & 32,3 \\
\hline Diploma/PT & 4 & 12,9 & 18 & 29 & 22 & 23,6 \\
\hline \multicolumn{7}{|l|}{ Pekerjaan } \\
\hline IRT & 5 & 16,1 & 15 & 24,2 & 20 & 21,5 \\
\hline Petani & 3 & 9,7 & 4 & 6,5 & 7 & 7,5 \\
\hline PNS & 2 & 6,5 & 9 & 14,5 & 11 & 11,8 \\
\hline Wiraswasta & 9 & 29 & 19 & 30,6 & 28 & 30,1 \\
\hline Pensiunan & 1 & 3,2 & 4 & 6,5 & 5 & 5,4 \\
\hline Lainnya & 11 & 35,5 & 11 & 17,7 & 22 & 23,7 \\
\hline
\end{tabular}

Sumber : Data Primer

Penelitian ini menemukan bahwa kepadatan hunian memiliki hubungan yang tidak bermakna sebagai faktor risiko kejadian penyakit TB Paru. Hasil analisis bivariat dengan uji Odds Ratio (OR) diperoleh nilai OR sebesar 1,969 pada tingkat kepercayaan $(\mathrm{CI})=$ 95\% dengan lower limit $=0,641$ dan upper limit $=6,049$. Oleh karena nilai lower limit dan upper limit mencakup nilai satu, sehingga nilai 1,969 dianggap tidak bermakna secara statistik.

Adanya hubungan yang tidak bermakna pada penelitian ini, karena pada kelompok kasus lebih banyak yang memiliki rumah dengan kondisi kepadatan hunian yang memenuhi syarat. Begitupun perbandingan kepadatan hunian yang tidak memenuhi syarat 
lebih banyak pada kelompok kontrol. Hal ini juga dimungkinkan karena jumlah sampel kasus yang digunakan relatif kecil. Walaupun secara teori dan beberapa penelitian yang mengemukakan bahwa kepadatan hunian dapat memiliki peran dalam penularan $\mathrm{TB}$ paru karena kepadatan hunian dapat menyebabkan infeksi silang (Cross infection) melalui udara ataupun "droplet" yang berasal dari penderita TB paru dalam rumah dengan kepadatan cukup tinggi. Untuk itu diperlukan suatu penelitian yang lebih lanjut terkait variabel kepadatan hunian dengan menggunakan sampel yang lebih besar sehingga dapat terlihat perbedaan yang lebih jelas antara kelompok kasus dengan kelompok kontrol.

Hasil penelitian ini sejalan dengan penelitian Adnani dan Asih (2006) yang menyatakan bahwa tidak ada hubungan yang bermakna antara kepadatan hunian dengan kejadian TB paru (OR = 1, CI 95\%;0,6116,568), dan Fatimah. S (2008) yang menyatakan bahwa tidak terdapat hubungan bermakna antara kepadatan hunian dengan kejadian $\mathrm{TB}$ paru $(\mathrm{OR}=0,820, \mathrm{CI}=95 \%$; 0,237-2,830).

Penelitian ini tidak sejalan dengan hasil penelitian Nugroho, A dkk (2009) yang menyatakan bahwa terdapat hubungan bermakna antara kepadatan hunian dengan kejadian TB paru $(\mathrm{OR}=2,429, \mathrm{CI}=95 \% ; 1,439$ - 4.058). Kepadatan hunian menjadi salah satu resiko orang yang terpajan kuman $\mathrm{TB}$ paru menjadi terinfeksi TB paru, untuk mencegah terjadinya penularan TB paru yaitu dengan mengurangi dan menghilangkan kondisi sosial yang mempertinggi resiko terjadinya infeksi seperti kepadatan hunian (Depkes, 2008).

Tabel 2. Besar Risiko TB Paru di Wilayah Kerja Puskesmas Binanga Kabupaten Mamuju Tahun 2016

\begin{tabular}{|c|c|c|c|c|c|c|c|}
\hline \multirow{3}{*}{ Variabel } & \multicolumn{4}{|c|}{ Kejadian TB Paru } & \multirow{3}{*}{$\mathbf{O R}$} & \multirow{3}{*}{$95 \% \mathrm{CI}$} & \multirow{3}{*}{$\mathbf{P}$} \\
\hline & \multicolumn{2}{|c|}{ Kasus } & \multicolumn{2}{|c|}{ Kontrol } & & & \\
\hline & $\mathbf{n}$ & $\%$ & $\mathbf{n}$ & $\%$ & & & \\
\hline \multicolumn{8}{|l|}{ Kepadatan Hunian } \\
\hline Tidak Memenuhi Syarat & 7 & 22,6 & 8 & 12,9 & \multirow{2}{*}{1,969} & \multirow{2}{*}{$0,641-6,049$} & \multirow{2}{*}{0,246} \\
\hline Memenuhi Syarat & 24 & 77,4 & 54 & 87,1 & & & \\
\hline \multicolumn{8}{|l|}{ Ventilasi } \\
\hline Tidak Memenuhi Syarat & 10 & 32,3 & 15 & 24,2 & \multirow{2}{*}{1,492} & \multirow{2}{*}{$0,576-3,863$} & \multirow{2}{*}{0,461} \\
\hline Memenuhi Syarat & 21 & 67,7 & 47 & 75,8 & & & \\
\hline \multicolumn{8}{|l|}{ Pencahayaaan } \\
\hline Tidak Memenuhi Syarat & 30 & 96,8 & 51 & 82,3 & 6471 & $0795-526$ & 0056 \\
\hline Memenuhi Syarat & 1 & 3,2 & 11 & 17,7 & D, & (2, & $0,0 J 0$ \\
\hline
\end{tabular}

Indikator kelembaban udara dalam rumah sangat erat dengan kondisi ventilasi. Ventilasi pada rumah memiliki fungsi untuk menjaga agar ruangan rumah selalu dalam kelembaban yang optimum. Ventilasi yang tidak mencukupi akan menyebabkan peningkatan kelembaban ruangan karena terjadinya proses penguapan dan penyerapan cairan dari kulit. Kelembaban ruangan yang tinggi akan menjadi media yang baik untuk tumbuh dan berkembang biaknya bakteribakteri patogen termasuk kuman tuberkulosis (Notoatmodjo, 2007). Kuman tuberkulosis mampu bertahan hidup di tempat yang gelap dan lembab, dan akan dormant di tempat kering dan dingin. Bakteri tuberkulosis paru akan mati pada pemanasan $100^{\circ} \mathrm{C}$ selama $5-10$ menit, atau pada suhu $60^{\circ} \mathrm{C}$ selama 30 menit. Kemampuan bakteri tuberkulosis berkembang pada suhu $35^{\circ} \mathrm{C}-37^{\circ} \mathrm{C}$, tidak tumbuh pada suhu $25^{\circ} \mathrm{C}$ atau lebih dari $40^{\circ} \mathrm{C}$, dan bakteri tuberkulosis akan hidup subur pada lingkungan dengan kelembaban tinggi, karena air membentuk lebih dari $80 \%$ volume sel bakteri dan merupakan media yang paling baik untuk pertumbuahan dan kelangsungan hidup sel bakteri (Gould dan Brooker, 2003) .

Penelitian ini menemukan bahwa Ventilasi memiliki hubungan yang tidak bermakna sebagai faktor risiko kejadian penyakit TB Paru. Hasil analisis bivariat dengan uji Odds Ratio (OR) diperoleh nilai OR 
sebesar 1,492 pada tingkat kepercayaan $(\mathrm{CI})=$ 95\% dengan lower limit $=0,576$ dan upper limit $=3,863$. Oleh karena nilai lower limit dan upper limit mencakup nilai satu, sehingga nilai 1,492 dianggap tidak bermakna secara statistik. Hasil penelitian ini sejalan dengan hasil penelitian Dewi, dkk (2016) yang menyatakan bahwa tidak ada hubungan yang bermakna antara luas ventilasi rumah dengan kejadian TB paru ( $p$ value $=0,226, \mathrm{OR}=2,212$ dan $95 \% \mathrm{CI}=$ $0,718-6,817)$.

Walaupun hasil penelitian ini tidak signifikan tetapi keberadaan ventilasi dapat menjadi faktor yang berpengaruh terhadap penularan TB paru, rumah dengan ventilasi yang kurang akan berpengaruh terhadap kejadian tuberkulosis paru (Notoatmodjo, 2007). Ventilasi rumah berfungsi untuk mengeluarkan udara yang tercemar (bakteri, CO2) di dalam rumah dan menggantinya dengan udara yang segar dan bersih atau untuk sirkulasi udara tempat masuknya cahaya ultra violet. Hal ini sejalan dengan penelitian Fatimah, S (2008) yang menyatakan bahwa keberadaan ventilasi memiliki resiko 5,17 kali terhadap penularan TB (OR 5,17, CI=95\%; 1,55 - 17,9). Dalam penelitian ini ventilasi merupakan faktor risiko yang berhubungan dengan kejadian tuberkulosis paru.

Keberadaan ventilasi mampu mengencerkan konsentrasi kuman TBC Paru dan kuman lain, terbawa keluar dan mati terkena sinar ultraviolet. Ventilasi juga dapat merupakan tempat untuk memasukkan sinar ultraviolet. Menurut Depkes RI (2003) ventilasi yang tidak baik dapat meyebabkan udara tidak nyaman (kepengapan, bronchitis, asma kambuh, masuk angin) dan udara kotor (penularan penyakit saluran pernafasan).

Suhu udara dan kelembaban ruangan sangat dipengaruhi oleh penghawaan dan pencahayaan. Pencahayaan yang kurang atau tidak lancar akan menjadikan ruangan terasa pengap atau sumpek dan akan menimbulkan kelembaban tinggi dalam ruangan (Kepmen Perumahan dan Prasarana Wilayah, 2002). Cahaya yang cukup untuk penerangan ruang dalam rumah merupakan kebutuhan kesehatan manusia. Cahaya mempunyai sifat dapat membunuh bakteri. Pencahayaan yang kurang akan menyebabkan kelembaban yang tinggi di dalam rumah dan sangat berpotensi bagi berkembangbiaknya kuman TB paru. Pencahayaan langsung maupun buatan harus menerangi seluruh ruangan dan memiliki intensitas 50 lux dan tidak menyilaukan.

Penelitian ini menemukan bahwa pencahayaan memiliki hubungan yang tidak bermakna sebagai faktor risiko kejadian penyakit TB Paru. Hasil analisis bivariat dengan uji Odds Ratio (OR) diperoleh nilai OR sebesar 6,471 pada tingkat kepercayaan $(\mathrm{CI})=$ 95\% dengan lower limit $=0,795$ dan upper limit $=52,6$. Oleh karena nilai lower limit dan upper limit mencakup nilai satu, sehingga nilai 6,471 dianggap tidak bermakna secara statistik. Adanya hubungan yang tidak bermakna pada penelitian ini, karena pada kelompok kontrol lebih banyak yang memiliki rumah dengan kondisi pencahayaan yang tidak memenuhi syarat dibandingkan dengan kelompok kasus, walaupun hampir seluruh responden pada kelompok kasus memiliki rumah dengan kondisi pencahayaan yang tidak memenuhi syarat, hal ini juga yang kemudian memungkinkan terjadinya rentang nilai CI yang terlalu lebar dan dianggap tidak bermakna secara statistik. Walaupun secara teori dan beberapa penelitian yang mengemukakan bahwa pencahayaan dapat memiliki peran dalam penularan TB paru karena kuman TB dapat bertahan lama dalam suatu ruangan salah satunya bergantung pada ketersedian pencahayaan alamiah yang mengandung ultraviolet.

Dalam ruangan yang lembab dan gelap kuman dapat tahan berhari-hari bahkan berbulan-bulan. Mati apabila terkena sinar matahari, sabun, lisol, karbol dan panas api, kuman mycobacterium tuberculosa akan mati dalam waktu 2 jam oleh sinar matahari; oleh tinctura iodii selama 5 menit dan juga oleh ethanol $80 \%$ dalam waktu 2 - 10 menit serta mati oleh fenol 5\% dalam waktu 24 jam. Rumah yang tidak masuk sinar matahari mempunyai risiko menderita tuberkulosis $3-7$ kali dibandingkan dengan rumah yang dimasuki sinar matahari. Hal ini sejalan dengan hasil penelitian Kurniasari, dkk (2012) yang menyatakan bahwa ada hubungan yang bermakna antara pencahayaan dengan kejadian $\mathrm{TB}$ paru dengan besar risiko $\mathrm{OR}=3,7$.

\section{KESIMPULAN DAN SARAN}

Hasil penelitian ini menunjukkan bahwa kepadatan hunian, ventilasi, dan pencahayaan tidak memiliki hubungan yang signifikan terhadap kejadian TB paru. Perlu dilakukan penelitian lanjutan dalam mengidentifikasi 
faktor risiko lingkungan perumahan pada skala wilayah yang lebih luas dengan sampel kasus yang lebih besar.

\section{UCAPAN TERIMAKASIH}

Terima kasih disampaikan kepada Direktur Poltekkes Kemenkes Mamuju atas pemberian izin dan pembiayaan terhadap penelitian ini, Dinas Kesehatan Kab. Mamuju dan Puskesmas Binanga yang telah mengizinkan melakukan penelitian dan responden yang berpartisipasi dalam penelitian ini.

\section{DAFTAR PUSTAKA}

Adnani, Hariza dan Mahastuti, Asih. (2006), Hubungan Kondisi Rumah dengan Penyakit TBC Paru di Wilayah Kerja Puskesmas Karangmojo II Kabupaten Gunung Kidul tahun 2005 - 2006. Yogyakarta: Jurnal Kesehatan Surya Medika.

Antoro, D.S, dkk (2010). Hubungan Faktor Lingkungan Fisik Rumah dan Respons Terhadap Praktik Pengobatan Strategi DOTS Dengan Penyakit Tb Paru di Kecamatan Tirto Kabupaten Pekalongan Tahun 2010. Jurnal Kesehatan Lingkungan Indonesia Vol.11 no.1 April 2011.

Badan Penelitian dan Pengembangan Kemenkes RI. Riset Kesehatan Dasar (2013). Jakarta: Badan Penelitian dan Pengembangan Kesehatan Kementerian Kesehatan RI.

Departemen Kesehatan Republik Indonesia. (2007). Pedoman Nasional Penanggulangan Tuberkulosis, (online). (http://www. tbindonesia. or.id/ pdf/ BPN_2007. pdf, diakses 21 Maret 2016).

Departemen Kesehatan (2003). Pedoman Nasional Penanggulangan Tuberkulosis. Jakarta: Departemen Kesehatan.

Dewi, Fitria Erlin, Suhartono, Adi, Sekundarno Mateus. (2016). Hubungan Faktor Lingkungan Rumah dengan Kejadian TB Paru di Kota Magelang. Jurnal Kesehatan Masyarakat, Vol.4/No.2, April 2016.

Fatimah Siti (2008). Faktor Kesehatan Lingkungan Rumah yang Berhubungan dengan Kejadian TB Paru di Kabupaten Cilacap Tahun 2008. Tesis-Universitas Diponegoro.

Gould, D. dan Brooker (2003). Mikrobiologi Terapan untuk Perawat. Jakarta: EGC.

Kemenkes RI. Profil Kesehatan (2015). Jakarta: Kementerian Kesehatan Republik Indonesia, 2016.

Kurniasari, Suharto, Cahyo. (2012). Faktor Risiko Kejadian Tuberkulosis Paru di Kecamatan Baturetno Kabupaten Wonogiri. Jurnal Media Kesehatan Masyarakat Indonesia, Vol.11/No.2, Oktober 2012.

Lemeshow, et.al. (1997). Besar Sampel dalam Penelitian Kesehatan. Terjemahan oleh Dibyo Pramono. Gadjah Mada University Press. Yogyakarta.

Menteri Permukiman dan Prasarana Wilayah RI. (2002). Keputusan Menteri Permukiman dan Prasarana Wilayah Nomor: 403/KPTS/M/2002 Tentang Pedoman Teknis Pembangunan Rumah Sederhana Sehat (Rs SEHAT). Jakarta: Kepmen Permukiman dan Prasarana.

Musadad, Anwar (2006). Hubungan Faktor Lingkungan Rumah dengan Penularan TB Paru Kontak Serumah. Jurnal Ekologi Kesehatan Vol.5 No.3: 486 - 496.

Notoatmodjo, S. (2007). Ilmu Kesehatan Masyarakat Ilmu Dan Seni. Jakarta: Rineka Cipta.

Nugroho. A. (2009). Faktor Risiko dan Sebaran Tubekulosis BTA Positif di Kota Kendari Provinsi Sulawesi Tenggara. Tesis. Universitas Gadjah Mada.

Rusnoto; Rahmatullah, Pasihan; dan Udiono, Ari. (2008). Faktor-Faktor Yang Berhubungan Dengan Kejadian Tb Paru Pada Usia Dewasa (Studi kasus di Balai Pencegahan Dan Pengobatan Penyakit Paru Pati), (online). (http://eprints. undip.ac.id/ 5283/1/ Rusnoto.pdf, diunduh 11 Maret Januari 2016). 